\title{
IAMJ
}

INTERNATIONAL

AYURVEDIC

MEDICAL JOURNAL

ISSN: 2320-5091

Impact Factor: 6.719

\section{AYURVEDIC MANAGEMENT OF SHITPITTA W.S.R. TO URTICARIA- A CASE REPORT}

\section{$\underline{\text { Shere Ashwini }}^{1}, \underline{\text { Rewadkar-Kole Meenakshi }}^{2}$}

${ }^{1}$ P.G. Scholar, ${ }^{2}$ Associate Professor, Department of Kayachikitsa, R.A. Podar Medical (Ayu) College, Mumbai, India.

Corresponding Author: shereashwini194@gmail.com

\section{https://doi.org/10.46607/iamj4609082021}

(Published Online: August 2021)

Open Access

C International Ayurvedic Medical Journal, India 2021

Article Received: 09/07//2021 - Peer Reviewed: 14/07/2021 - Accepted for Publication: 15/07/2021

\section{Check for updates}

\section{ABSTRACT}

Urticaria is an allergic reaction of the skin to a variety of exogenous and endogenous antigens. It is a common disease nowadays, characterized by pale red rashes and severe itching caused by an allergic reaction. Vascular dilatation, the resultant dermal oedema and pruritis are due to the releases of histamine and other mediators from mast cells. Ayurvedic classics mentioned this similar condition as shitpitta, among twakroga which is vaatpradhan tridosha in nature. Symptoms mentioned by aacharyas are shotha, toda, kandu and daha. Even after the availability of newer medicine, there is a lack of promising results against this ailment. Moreover, the use of drugs like antihistamines and corticosteroids lead to various side effects. The study aims to evaluate the effect of ayurvedic treatment in the management of shitpitta with special reference to urticaria. This study deals with a case of chronic urticaria, where a male patient was given an ayurvedic therapy which included shodhan-shamanaushadi and sthanik treatment on an OPD basis for 3 months. Criteria's like shotha, toda, kandu and daha were assessed before and after the treatment \& significant result was found. The conclusion was drawn that given ayurvedic therapy was found to be significantly effective in the management of urticaria.

Keywords: Shitpitta, Twakroga, Urticaria, Shodhan, Shamana

\section{INTRODUCTION}

As per the modern aspect, shitpitta is correlated with urticaria. It is described as primary cutaneous disorder consisting of a recurrent, transient, cutaneous swelling with the erythema. There is a formation of 'wheal \& 
flare' cutaneous lesions involving only the superficial portion of the dermis. ${ }^{1}$ The lesion varies in size from $1 \mathrm{~mm}$ to several centimetres. It is defined as evanescent discrete areas of dermal oedema, often centrally white due to masking of local blood supply by fluid. ${ }^{2}$ There are multiple potential causes for it. Most causes are idiopathic, other causes include allergies to endogenous and exogenous agents and physical forms (like heat, cold, friction and vibration). ${ }^{3}$ Epidemiology of urticaria is increasing nowadays due to industrialization and agriculture. Approximately 15 to $20 \%$ of the general population will have urticaria, at least once during their lifetime. A person of any age may experience urticaria, but it occurs most frequently after adolescence, with the highest incidence in young adults. Urticaria is classified into two types according to its duration. 1. Acute urticaria-it is of less than 6 weeks duration, 2. Chronic urticaria- it is of more than 6 weeks duration, with daily or episodic wheals. Due to urbanization, lifestyle is changed a lot, dietary habits are also changed; use of chemicals for fertilization and preparation of food, more use of junk food and packed food is found. All these conditions lead to the vitiation of dosha and dhatu. Shitpitta is a condition where all three dosha gets vitiated but vata vitiation is more. Dhatu involved in this is mainly rasa and rakta. In modern science, it has only symptomatic treatment (with antihistamines and steroids) and does not constitute a complete cure. Prolonged administration is often required, this places the patient at risk of adverse effects. Treatment for shitpitta according to ayurveda include both shodhan and shaman chikitsa. Various aushadhi yoga is mentioned for udarda, kotha which can also be used for shitpitta. The main advantage of ayurvedic treatment is that it helps to control the recurrence and severity of shitpitta with the correct use of shodhan and shaman chikitsa and pathya-apathya palana.

\section{PATHOPHYSIOLOGY}

Most cases of urticaria are reactions of type 1 hypersensitivity which are mediated by IgE antibodies fixed on the mast cells, located on the surface of tissue mast cells and basophils. The antigen reaches the skin via the bloodstream, react with $\operatorname{IgE}$ antibodies fixed on the mast cell. This leads to mast cell degranulation and release of histamine \& other vasoactive mediators, which is the basis of urticaria. These mediators act on the vascular epithelium and cause vasodilatation and result in erythema, swelling and itching. ${ }^{4}$ All these phenomena result in the formation of wheals. Samprapti of shitpitta occurs due to hetusevan (katu, amla, lavana rasa and ushna, tikshan guna pradhana) agnimandya and apakva aahararasa is produced, which is vidagdha in nature. It leads to vidagdha \& abhishyandi guna vriddhi in rasa- raktadi dhatu and same gunatmaka kapha pitta dosha are produced. There is an indulgence of simultaneous vata prakopaka hetu, tiryak gati of vata spreads these doshas all over the body, and sthana sanshraya at twak occurs. Thus, due to tikshna, ushna, vidagdha guna symptoms like saurambha, toda, kandu \& daha are produced. $^{5}$

\section{CASE STUDY}

A 50-year male patient, a fisherman by occupation, came to OPD with complaints of rashes and itching all over the body (on and off) for 2 years. The frequency of appearance of lesions was 2-3 times/week. The itching was severe, the patient was taking antihistamines during each attack (2 to 3 times a week).

On examination, the lesions were reddish, with wheals over the back region. It had severe itching, burning sensation, swelling and a pricking sensation also. There was no discharge or exudation seen. Symptoms were aggravated during exposure to cold and during the night.

No H/O DM/HTN/BA/or any other major illness $\mathrm{H} / \mathrm{O}$ alcohol addiction since for 5 years (taking once or twice a week), Family history- bronchial asthma to mother, Diet history - was taking nonveg (eggs and fishes) 3 to 4 times a week, taking spicy and oily diet, food predominance in lavana, katu and amla rasa (curd, pickle, papad etc.), History of repeated exposure to cold environment. Systemic examination- CVS$\mathrm{S}_{1} \mathrm{~S}_{2}$ normal, CNS- conscious \& oriented, RS- AEBE Clear, all routine blood investigations were done. Rugna prakruti was pitta-vata pradhan and doshdushti was tridoshaja. 


\section{TREATMENT GIVEN}

\section{Oral Drugs:}

1. Aarogyavardhani vati $500 \mathrm{mg} \mathrm{BD}$

2. Aaragvadha Kapila vati $1 \mathrm{gm}$ HS daily

3. Haridrakhanda 5gm BD

4. Mahamanjishthadi kwatha 30cc BD

5. Bhringaraja aasava $30 \mathrm{cc} \mathrm{BD}$
Sthanik treatment: Bruhat marichyadi taila was given for local application over lesions

Shodhana: Siravedha was done - 3 sittings

The above said treatment was given for 3 months and the patient was advised to give follow-up every 15 days. Criteria were assessed before and after the treatment i.e. after 3 months.

\section{OBSERVATION AND RESULT}

Table 1: Parameters of assessment

\begin{tabular}{|c|c|c|}
\hline Parameters of assessment & Before treatment & After treatment \\
\hline 1. Shotha (edema) & ++ & + \\
\hline 2. Toda (pricking sensation) & +++ & + \\
\hline 3. Kandu (itching) & +++ & + \\
\hline 4. Daha (burning sensation) & ++ & - \\
\hline 5. No of wheals & (11 to 30$)$ & $(<10)$ \\
\hline 6. Size of lesions & $(>3 \mathrm{~cm})$ & $(1-3 \mathrm{~cm})$ \\
\hline 7. Frequency of appearance & (2-3 times a week) & Once a week \\
\hline 8. Frequency of use of antihistamines & (2-3 times a week) & Not required \\
\hline
\end{tabular}

\{Mild (occasionally) - +, Moderate (disturbing normal activity) - ++, Severe (disturbing sleep) - +++

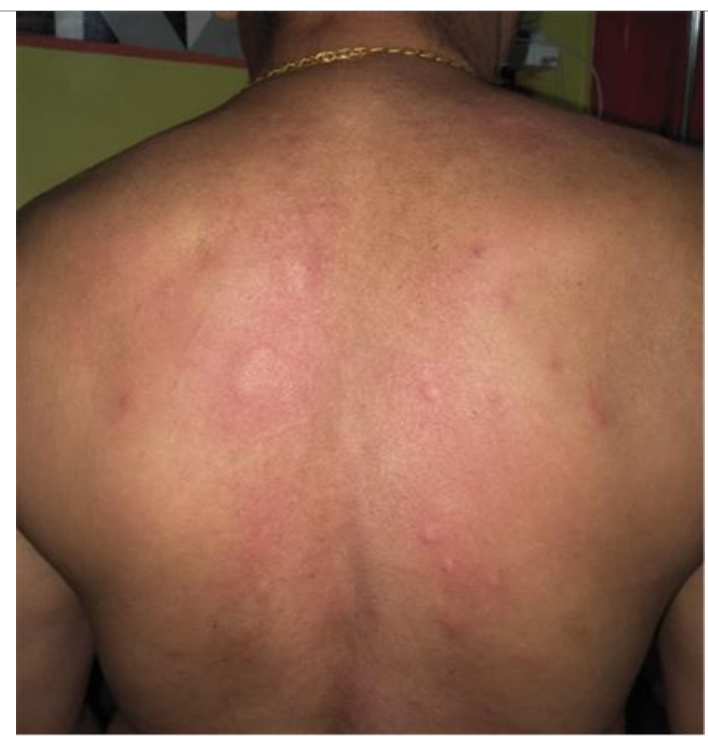

Fig. 1 [Before treatment]

\section{DISCUSSION}

In present case report, etiopathogenesis (samprapti) of the disease can be postulated as, hetusevana like aahara- katu, amla, lavana rasa pradhan and ushna, tikshna guna pradhan (eg. nonveg, chillies, pickle, curd, papad, alcohol) leads to agnimandya and aama aahara rasa nirmiti (vidagdha, ushna, tikshna,

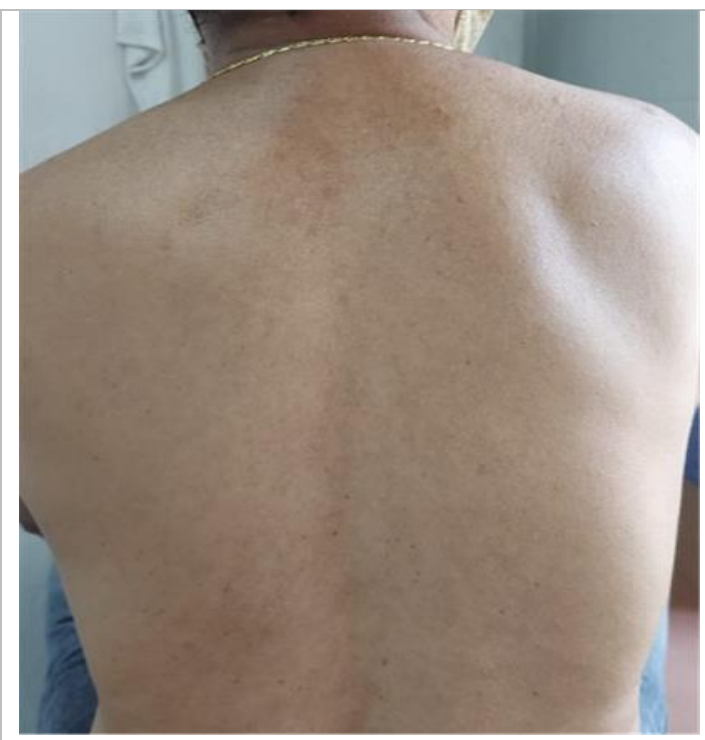

Fig. 2 [After treatment]

abhishyandi gunatmaka). Rasa and rakta dhatu are also produced of same properties, vidagdha, ushna and abhishyandi guna vriddhi of kapha pitta dosha occurs. Simultaneous indulgence of exposure to cold environment (eg. drinking cold water, ice-cream, shita rutu, shita jala \& vayu sparsh) leads to shita and chala guna vriddhi of vata dosha. Both these factors lead to 
avarodh to prakruta gati of vata dosha. Due to tiryak gati of vata, vidagdha, abhishyandi, ushna, tikshna guna kapha pitta dosha are spread through whole body, sthansanshraya at twacha occurs and asahtva is produced. Symptoms like saurambha, aaraktata, $k a n d u$ etc are produced.

Probable mode of action of medicines, Aaragvadha Kapila tablet- It contains aaragvadha, which is rechan and said to be koshthashuddikar. ${ }^{6}$ Thus helps in Kapha-pitta shodhana. It also has anti-inflammatory action. It contains kampillak which is also rechana and acts as rakta-shodhana. Aarogyavardhani vati- It contains parad -gandhak kajjali which is sukshma strotogami and yogavahi, it does strotoshodhana. It acts as kledahara and shothahara. Kutaki act as yakruttotejak and acts on rasa rakta dhatu. Chitrak helps in normalizing dhatwagni. Haridrakhanda- It contains triphala, trivrutta which act as rechana and helps in pittarechana. Musta and nagakeshar acts on rakta dhatvagni \& helps in rakta prasadana. Haridra is tikta, ushna helps in relieving itching. Mahamanjishthadi kwath- it helps in balancing vitiation of doshas, particularly effective in maintaining pitta dosha. It acts as a blood purifier, helps in maintaining healthy blood circulation. Bhringarajasava- it contains bhringaraja as the main ingredient. It is katu, ushna acts on the liver, helps in regulation of pitta dosha. It also has antiallergic and anti-inflammatory properties. $^{7}$ Bruhat marichyadi tail- its main ingredient is maricha and sarshapa taila, which act as kapha pachana and vata shamana and helps in relieving itching. Siravedha- letting out of vitiated blood is siravedha. It improves microcirculation in the sira and help in reducing oedema, itching and burning.

\section{CONCLUSION}

The ayurvedic management given in shitpitaa, showed significant improvement. This was a case study, where multiple ayurvedic medicines were given and local applications used, which gave relief to the patient symptomatically. But still, further study is needed for more evaluation.

\section{ACKNOWLEDGEMENT}

I would like to acknowledge my guide Dr. Meenakshi Rewadkar-Kole (Associate professor, Kayachikitsa department), this article was supported by her. I also thank my colleagues and our medical institute.

\section{REFERENCES}

1. K George Mathew, Medicine, Reed Elsevier India Pvt. Ltd. $5^{\text {th }}$ edition, 2015;276

2. Stuart H Ralston, Davidson's principle and practice of Medicine, Elsevier Ltd. 23 ${ }^{\text {rd }}$ edition, 2018;1252

3. Siddharth N Shah, API Textbook of Medicine, The association of physicians of India, $8^{\text {th }}$ edition, 2009;1395

4. Uday Khopkar, Skin diseases and sexually transmitted infections, CBS publishers and distributors Pvt. Ltd. $7^{\text {th }}$ edition, 2019;130

5. Yadunandan Upadhaya, Madhav nidana by Madhavakara with madhukosha Sanskrit commentary, Varanasi, Chaukhamba prakashana, reprint 2013;200

6. K.C. Chunekar, Bhavaprakash Nighantu of sri bhavmishra, Chaukhamba Bharati academy Varanasi, 2010;66

7. Seelingere G., Mefort I., Schemp C. M. Antioxidant, anti-inflammatory and anti-allergic activities of luteolin. Planta Medica. 2008; 74 (14): 1667-1677

\section{Source of Support: Nil \\ Conflict of Interest: None Declared}

How to cite this URL: Ashwini Shere \& Rewadkar-Kole Meenakshi: Ayurvedic Management Of Shitpitta W.S.R. To Urticaria- A Case Report. International Ayurvedic Medical Journal \{online\} 2021 \{cited August 2021\} Available from: http://www.iamj.in/posts/images/upload/1894_1897.pdf 